\title{
Pengendalian Jentik Aedes sp. Melalui Pendekatan Keluarga di Provinsi Papua
}

\author{
Larvae Control Through Family ApproachiIn Papua
}

\author{
Revi Rosavika Kinansi ${ }^{1 *}$, Tri Wuri Sastuti², dan Zumrotus Sholichah ${ }^{3}$ \\ ${ }^{1}$ Balai Besar Litbang Vektor dan Reservoir Penyakit Salatiga, Badan Litbangkes, Kementerian Kesehatan \\ RI, Jl. Hasanudin 123 Salatiga, Jawa Tengah, Indonesia \\ ${ }^{2}$ Loka Litbangkes Baturaja, Badan Litbangkes, Kementerian Kesehatan RI, Jl. Ahmad Yani KM.7 Baturaja, \\ Sumatera Selatan \\ ${ }^{3}$ Loka Litbangkes Banjarnegara, Badan Litbangkes, Kementerian Kesehatan RI, Jl. Selamanik No. 16A \\ Banjarnegara, Jawa Tengah \\ *Korespondensi Penulis: revikinansi@gmail.com
}

Submitted: 05-01-2018, Revised: 30-07-2018, Accepted: 30-07-2018

DOI: http://dx.doi.org/10.22435/mpk.v28i2.120

\begin{abstract}
Abstrak
Adanya permasalahan penyakit tular vektor Demam Berdarah Dengue (DBD) yang semakin lama tidak kunjung berkurang malah semakin bertambah menyebabkan Kementerian Kesehatan RI melakukan studi Riset Khusus Vektor dan Reservoir pada tahun 2015 di 4 provinsi, yaitu Provinsi Sumatera Selatan, Jawa Tengah, Sulawesi Tengah, dan Papua. Penelitian ini bertujuan untuk mengetahui hubungan peran serta keluarga dalam masyarakat terhadap keberadaan jentik Aedes sp. di Provinsi Papua. Perilaku masyarakat yang akan diteliti antara lain: peletakan tempat penampungan air, penutupan tempat penampungan air, pemeliharaan ikan pada tempat penampungan air, penaburan larvasida pada setiap tempat penampungan air, dan pengurasan tempat penampungan air. Keberadaan jentik nyamuk merupakan indikator dari potensi keterjangkitan masyarakat akan DBD. Sampel dalam analisis ini yaitu 100 rumah per kabupaten yang menjadi wilayah penelitian Riset Khusus Vektor dan Reservoir 2015 di Provinsi Papua. Metode pengambilan jentik dilakukan dengan mengambil jentik atau pupa Aedes sp. menggunakan pipet plastik dan dipindahkan ke dalam tabung vial menggunakan teknik Single Larvae Method. Hasil penelitian menunjukkan dari keseluruhan kontainer yang diletakkan di dalam rumah, $28,27 \%$ positif jentik. Kontainer yang tidak dikuras memiliki peluang 15 kali positif jentik dibandingkan dengan kontainer yang rajin dikuras seminggu sekali. Penelitian ini juga menunjukkan hasil memelihara ikan dalam kontainer memiliki rasio tidak terdapat jentik dengan terdapat jentik yaitu 91:9. Penaburan larvasida tidak memiliki pengaruh nyata terhadap ada dan tidaknya jentik di Provinsi Papua. Peran keluarga dalam lingkungan masyarakat perlu lebih ditingkatkan lagi dan didukung oleh peran petugas kesehatan dalam penanggulangan penyakit demam berdarah dengue.
\end{abstract}

Kata kunci: jentik, Aedes sp., DBD, kontainer, peran serta keluarga, masyarakat

\begin{abstract}
Dengue Hemorrhagic Fever has not been reduced yet, therefore, the Ministry of Health has conducted a Riset Khusus Vektor dan Reservoir in 2015 in 4 provinces, South Sumatera, Central Java, Central Sulawesi and Papua. This study aimed to determine the relationship of family participation in the community to the presence of larvae Aedes sp. in Papua Province. Community attitudes to be studied include: the laying of water reservoirs, the closure of water reservoirs, the maintenance of fish in water reservoirs, the sowing of larvicides at each water reservoir and the draining of water reservoirs. The presence of mosquito larvae is an indicator of the potential of community awareness of DHF. The sample in this analysis was 100 houses per district which was the Riset Khusus Vektor dan Reservoir 2015 area in Papua. The method of taking larvae wass done by taking a larva or pupa Aedes sp. using plastic pipette and transferred into vial tube using Single Larvae Method technique. The results showed from the overall container placed in the house, 28.27 percent were positive larvae. Non-drained containers had a 15 times positive chance of larvae compared to containers that are diligently drained once a week. This study also showed that the results of keeping fish in containers have a ratio of no larvae, with larvae being 91: 9. Larvaside sowing had no
\end{abstract}


real effect on the presence or absence of larvae in Papua Province. The role of families in the community environment needs to be further improved and supported by the role of health workers in the prevention of dengue hemorrhagic fever.

Keywords: Larvae, Aedes sp., DHF, container,family participation, community

\section{PENDAHULUAN}

Prioritas pembangunan kesehatan di Indonesia tahun 2015-2019 pada penyakit menular masih tertuju pada penyakit HIV/AIDS, tuberkulosis, malaria, demam berdarah, influenza, dan flu burung. ${ }^{1}$ Pada tahun 2015-2019 hampir seluruh kabupaten/kota di Indonesia terjangkit demam berdarah dengue (DBD). Pada tahun 2015 sebanyak $86,77 \%$ kabupaten/kota yang terjangkit demam berdarah dan meningkat menjadi 90,08\% kabupaten/kota pada tahun 2016, namun pada tahun 2017 terjadi penurunan menjadi 84,44\% kabupaten/kota. ${ }^{2}$ Upaya pencapaian prioritas pembangunan kesehatan tahun 2015-2019 dalam Program Indonesia Sehat dilaksanakan dengan mendayagunakan segenap potensi yang ada, baik dari pemerintah pusat, provinsi, kabupaten/kota, maupun masyarakat. Pembangunan kesehatan dimulai dari unit terkecil dari masyarakat, yaitu keluarga. ${ }^{1}$ Pemahaman penyakit DBD dan penanggulangannya masih kurang, yang tampak pada masih dibebankannya masalah DBD dan tanggung jawabnya pada sektor kesehatan, padahal DBD sebenarnya harus menjadi tanggung jawab semua pihak karena erat kaitannya dengan kebersihan dan perilaku manusia. Penanggulangan penyakit DBD lebih banyak terkait dengan peran serta masyarakat. ${ }^{3}$ Banyak faktor yang mempengaruhi keberhasilan pemicuan motivasi masyarakat untuk pengendalian populasi Aedes sp. Faktor tempat dan karakteristik penduduk diduga merupakan faktor yang berpengaruh bagi proses peningkatan motivasi. ${ }^{4}$ Salah satu dampak dari motivasi yang muncul adalah adanya komitmen warga dalam pertemuan warga. Selain masyarakat, adanya komitmen dari pemuka masyarakat setempat untuk mendukung program ini merupakan keharusan, karena dengan dukungan dalam pertemuan-pertemuan di masyarakat, membuat motivasi masyarakat menjadi lebih tinggi untuk berpartisipasi. Seorang tokohmempunyai pengaruh yang besar dalam menggerakkan masyarakat luas, karena masyarakat umum lebih mudah menerima apa yang dijelaskan oleh pemuka masyarakatnya. ${ }^{5}$

Menurut Sutari, ${ }^{6}$ penanggulangan demam berdarah pada keluarga sampai saat ini masih belum berjalan dengan baik, penyakit demam berdarah terus saja terjadi dikarenakan kurangnya kesadaran untuk menjaga lingkungan oleh keluarga. Keluarga berfungsi untuk mempertahankan keadaan kesehatan anggota keluarga agar tetap memiliki produktivitas yang tinggi. Setiap keluarga harus mempertahankan suasana rumah yang menguntungkan untuk kesehatan dan perkembangan kepribadian anggota keluarganya. Pemerintah mengharapkan setiap keluarga dapat meningkatkan kesadaran, kemauan dan kemampuan hidup dengan perilaku dan dalam lingkungan yang sehat. Konsep pendekatan keluarga dalam analisis ini adalah mengukur hubungan perilaku hidup sehat setiap keluarga dengan keberadaan jentik Aedes sp. Perilaku hidup sehat keluarga yang diteliti meliputi pemilihan letak tempat penampungan air, penutupan tempat penampungan air, pemeliharaan ikan pada tempat penampungan air, penaburan larvisida pada setiap tempat penampungan air, dan pengurasan tempat penampungan air pada satu minggu terakhir. Sanitasi lingkungan merupakan hal yang harus diperhatikan oleh keluarga dan masyarakat. Sanitasi lingkungan biasanya dilakukan secara bergotong royong oleh seluruh warga di lingkungan tersebut, tetapi tidak semua masyarakat yang merasa bertanggung jawab akan keadaan sanitasi lingkungannya apalagi yang tinggal di perumahan. ${ }^{7}$ Dari hasil penelitian yang di lakukan oleh Lawira, ${ }^{7}$ bahwa kebiasaan membersihkan halaman rumah sering dilakukan, kamar mandi, WC, semua dalam keadaan bersih tetapi didapatkan beberapa kendala yaitu kebersihan seperti selokan, bak penampungan air, bubuk larvasida, kebiasan menggantung pakaian, dan kebiasaan membuang sampah masih dalam kategori kurang. Hal ini masih memicu terjadinya angka kesakitan terutama penyakit infeksi seperti demam berdarah karena tempat tersebut merupakan media dari nyamuk demam berdarah untuk berkembang biak apalagi pada musim hujan seperti air di selokan, tempat penampungan air, daun-daun, sabuk kelapa, dan potongan bambu, karena akan terjadi genangan air pada benda-benda tersebut. Hal ini yang melatarbelakangi dalam penelitian ini, bagaimana peran serta keluarga dalam masyarakat untuk pengendalian jentik Aedes sp. sebagai vektor penyakit DBD.

Monitoring keberadaan nyamuk dapat dilakukan dengan pemberantasan sarang nyamuk (PSN) secara periodik oleh masyarakat yang 
dikoordinir oleh RT/RW dalam bentuk PSN dengan pesan inti $3 \mathrm{M}$ plus. Keberhasilan kegiatan PSN antara lain dapat diukur dengan Angka Bebas Jentik (ABJ), House Index (HI), Container Index (CI), dan Breteau Index (BI). Apabila ABJ lebih atau sama dengan 95\% diharapkan penularan DBD dapat dicegah atau dikurangi. ${ }^{8}$ Salah satu hal yang mempengaruhi kepadatan nyamuk Aedes sp. adalah keberadaan manusia sebagai penyedia darah untuk maturasi telur nyamuk. Semakin padat jumlah manusia di suatu tempat maka semakin banyak pula nyamuk Aedes sp. yang berada di tempat tersebut. Sebaran nyamuk dipengaruhi oleh keberadaan manusia sebagai penyedia darah, ditunjang oleh tanaman dan perabotan sebagai tempat peristirahatan. ${ }^{9}$ Kehidupan nyamuk sangat ditentukan oleh keadaan lingkungan yang ada seperti suhu, kelembaban dan curah hujan. ${ }^{10}$ Untuk mengetahui kepadatan vektor di suatu lokasi dapat dilakukan survei jentik. Survei jentik dilakukan dengan cara pemeriksaan terhadap semua tempat air di dalam dan di luar rumah dari 100 rumah yang diperiksa di suatu daerah untuk mengetahui ada tidaknya jentik. ${ }^{11}$ Monitoring kepadatan populasi nyamuk sangat penting untuk membantu dalam penentuan evaluasi adanya ancaman penyakit di setiap wilayah dan untuk menentukan apakah suatu tindakan pemberantasan nyamuk sebagai vektor penyebar penyakit perlu dilakukan. ${ }^{8}$

DBD adalah penyakit demam akut yang dapat menyebabkan kematian dan disebabkan oleh empat serotipe virus dari genus Flavivirus. Infeksi oleh satu serotipe virus dengue menyebabkan terjadinya kekebalan yang lama terhadap serotipe virus tersebut. Pada waktu terjadi epidemi di dalam darah seorang penderita dapat beredar lebih dari satu serotipe virus dengue. Dengue ditularkan oleh genus Aedes, nyamuk yang tersebar luas di daerah tropis dan subtropis di seluruh dunia. Virus dengue ditularkan dari seorang penderita ke orang lain melalui gigitan nyamuk Aedes. ${ }^{12}$ Dilaporkan lebih dari 100 negara di daerah tropis terinfeksi virus dengue dan infeksi virus ini menyerang semua usia. Sebanyak 95\% menyerang pada anak usia di bawah 15 tahun dan sekitar $\geq 5 \%$ terjadi pada bayi. Risiko manusia di dunia terserang virus DBD adalah 500.000: 50 juta jiwa. Dari 500.000 kasus tersebut memiliki angka kematian sekitar $20 \%{ }^{13}$ Asia menempati urutan pertama dalam jumlah penderita demam berdarah di tiap tahunnya. Sementara itu terhitung sejak tahun 1968 hingga tahun 2009, World Health Organization (WHO) mencatat negara Indonesia sebagai negara dengan kasus DBD tertinggi di Asia
Tenggara. ${ }^{14}$ Berdasarkan data Dirjen Pencegahan dan Pengendalian Penyakit (P2P) Kementerian Kesehatan RI pada tahun 2017, dengan jumlah penduduk sebesar 261.890.872, jumlah kasus DBD di Indonesia mencapai 59.047 kasus dengan IR (Incident Rate) 22,55 per 100.000 penduduk dan 444 penduduk meninggal karena DBD. Provinsi Papua merupakan salah satu provinsi di Indonesia yang memiliki kabupaten/kota yang terjangkit demam berdarah. Pada tahun 2015 terdapat $17,24 \%$ kabupaten/kota yang terjangkit demam berdarah, tahun 2016 meningkat tinggi menjadi 34,48\% kabupaten/kota dan pada tahun 2017 sedikit menurun menjadi 27,59\% kabupaten/ kota. ${ }^{1}$ Di Provinsi Papua, pada tahun 2017 terdapat jumlah kasus DBD yang cukup tinggi yaitu sebanyak 269 kasus dengan IR 8,24 per 100.000 penduduk. $^{2}$

Indeks kepadatan vektor demam berdarah dengue antara lain House index (HI), Container Index (CI), Breteau Index (BI) dan Angka Bebas Jentik (ABJ), merupakan parameter entomologi yang mempunyai relevansi langsung dengan dinamika penularan penyakit. ${ }^{15}$

Status kepadatan vektor DBD diperoleh berdasarkan indikator $\mathrm{HI}, \mathrm{CI}, \mathrm{BI}$ dan $\mathrm{ABJ}^{16}$, yaitu:

\begin{tabular}{|c|c|}
\hline \multirow{2}{*}{$\begin{array}{l}\text { House Index }= \\
\qquad(\mathrm{HI})\end{array}$} & $\begin{array}{l}\text { Jumlah kontainer yang ditemukan } \\
\text { jentik x } 100 \%\end{array}$ \\
\hline & Jumlah rumah yang diperiksa \\
\hline \multirow{2}{*}{$\begin{array}{l}\text { Container Index }= \\
\qquad(\mathrm{CI})\end{array}$} & $\begin{array}{l}\text { Jumlah kontainer yang ditemukan } \\
\text { jentik x } 100 \%\end{array}$ \\
\hline & Jumlah kontainer yang diperiksa \\
\hline \multirow{2}{*}{$\begin{array}{l}\text { Breteau Index = } \\
\qquad(\mathrm{BI})\end{array}$} & $\begin{array}{c}=\text { Jumlah kontainer yang ditemukan } \\
\text { jentik x } 100 \%\end{array}$ \\
\hline & Jumlah rumah yang diperiksa \\
\hline \multirow{2}{*}{$\begin{array}{l}\text { Angka Bebas } \\
\text { Jentik }(\mathrm{ABJ})=\end{array}$} & $\begin{array}{c}=\text { Jumlah rumah yang tidak } \\
\text { ditemukan jentik x 100\% }\end{array}$ \\
\hline & Jumlah rumah yang diperiksa \\
\hline
\end{tabular}

Selama ini Provinsi Papua adalah provinsi endemis vektor malaria. Riset Khusus Vektor dan Reservoir 2015 memberi informasi bahwa DBD di Provinsi Papua dilaporkan sebanyak 470 kasus dengan kematian akibat DBD sebanyak 8 kasus. Penelitian ini menganalisis seberapa besar pengaruh perilaku masyarakat di 3 kabupaten di Provinsi Papua terhadap keberadaan jentik Aedes sp. Cara paling baik untuk mencegah penyakit DBD adalah dengan pemberantasan jentik nyamuk penularnya atau dikenal dengan istilah Pemberantasan Sarang Nyamuk Demam Berdarah Dengue (PSN-DBD). ${ }^{17}$ Yuwono dalam Yotopranoto $^{18}$ menyatakan bahwa dari beberapa survei yang dilakukan di beberapa kota di Indonesia menunjukkan tempat perindukan yang 
paling potensial adalah di tempat penampungan air yang digunakan untuk keperluan sehari-hari seperti drum, tempayan kontainer, bak mandi, bak WC, ember dan sejenisnya. Berdasarkan penelitian sejenis, tempat penampungan air yang diperiksa meliputi bak mandi, gentong, ember, penampungan kulkas, penampungan dispenser, perangkap semut, vas bunga, kolam dengan air yang tidak berarus, dan tidak ada ikan di dalamnya. ${ }^{19}$ Oleh sebab itu kebijakan pemerintah dalam pengendalian vektor DBD lebih menitikberatkan pada program PSN, walaupun cara ini sangat tergantung pada peran serta masyarakat. ${ }^{20}$

Tujuan dilakukan analisis ini adalah mengetahui hubungan peran serta keluarga dalam masyarakat terhadap keberadaan jentik Aedes sp. di Provinsi Papua. Perilaku masyarakat yang akan diteliti antara lain: peletakan tempat penampungan air, penutupan tempat penampungan air, pemeliharaan ikan pada tempat penampungan air, penaburan larvasida pada setiap tempat penampungan air, dan pengurasan tempat penampungan air.

\section{METODE}

Populasi dalam analisis ini adalah seluruh rumah ekosistem DBD yang berada pada 3 titik/ kabupaten yang menjadi wilayah penelitian Riset Khusus Vektora 2015 di Propinsi Papua yaitu di Kabupaten Biak Numfor, Kabupaten Merauke dan Kabupaten Sarmi. Sampel dalam analisis ini yaitu 100 rumah per kabupaten yang menjadi wilayah penelitian Riset Khusus Vektora 2015 di Propinsi Papua. Jika pada tempat penampungan air yang diperiksa ditemukan jentik atau pupa Aedes sp., maka diambil dengan menggunakan pipet plastik dandipindahkankedalam tabung vialmenggunakan teknik Single Larvae Method. Pemilihan rumah yang disurvei dengan teknik random sampling. Setiap 1 kabupaten diambil 100 rumah sebagai sampel terpilih. Dalam tiap rumah diperiksa tempat penampungan air yang ada. Variabel terikat penelitian ini adalah keberadaan jentik Aedes sp. Data didapat dari Kuesioner Vektora J04-DBD Blok X entomologi DBD Kolom 14 mengenai keberadaan jentik (1. Ada jentik, 2. Tidak ada jentik) dan J04-DBD Blok X entomologi DBD Kolom 16 mengenai spesies jentik yang ada (1. Aedes aegypti, 2. Aedes albopictus, 3. Non-Aedes). Variabel bebas penelitian antara lain data peletakan kontainer didapat dari kuesioner vektora J04-DBD Blok X entomologi DBD Kolom 4 mengenai letak/tempat kontainer (1. Dalam rumah, 2. Luar rumah), data penutupan kontainer didapat dari kuesioner vektora J04-DBD Blok X entomologi DBD Kolom 7 mengenai penutupan kontainer (1. Tertutup, 2. Tidak tertutup), data pengurasan kontainer 1 minggu terakhir didapat dari kuesioner vektora J04-DBD Blok X entomologi DBD Kolom 10 mengenai pengurasan kontainer 1 minggu terakhir (1. Dikuras, 2. Tidak dikuras), data pemeliharaan ikan didapat dari kuesioner vektora J04-DBD Blok X. Entomologi DBD Kolom 11 mengenai pemeliharaan ikan (1. Pelihara ikan, 2. Tidak pelihara ikan), data penaburan larvasida didapat dari kuesioner vektora J04-DBD Blok X entomologi DBD Kolom 12 mengenai penaburan larvasida (1. Ditaburi, 2. Tidak ditaburi). Analisis univariat dilakukan terhadap seluruh variabel untuk mengetahui karakteristik perilaku masyarakat berdasarkan variabel terpilih. Analisis bivariat dilakukan untuk mengkaji korelasi antara variabel peletakan tempat penampungan air, kondisi tempat penampungan air (terbuka/tertutup), pengurasan tempat penampungan air, pemeliharaan ikan predator jentik, dan pemberian larvasida dalam tempat penampungan air terhadap keberadaan jentik. Analisis bivariat yang dilakukan adalah analisis regresi logistik dan mencari OR masingmasing hubungan variabel. Hasil analisis disajikan dalam bentuk tabel dan diagram yang kemudian dinarasikan.

\section{HASIL}

Pemberantasan jentik merupakan kunci strategi program pengendalian vektor di seluruh dunia. ${ }^{21}$ Upaya untuk melakukan pencegahan dan pemberantasan penyakit DBD yang paling penting adalah dengan mengendalikan nyamuk Ae. aegypti sebagai vektor utama. Oleh karena nyamuk tersebut hidup di dalam dan sekitar rumah penduduk, maka partisipasi masyarakat dalam upaya pengendalian vektor Ae.aegypti sangat menentukan keberhasilannya. ${ }^{22}$ Berdasarkan Tabel 1 keberadaan jentik di Provinsi Papua pada tahun 2015 sebesar 31,6\%. Hal ini memberikan informasi bahwa masyarakat di Papua sudah cukup mengetahui bahwa penting sekali untuk menerapkan PSN (Pemberantasan Sarang Nyamuk) mulai dari lingkup terkecil di keluarga sehingga diharapkan populasi jentik dan nyamuk setiap tahun berkurang.

Berdasarkan Gambar 1, dapat dilihat bahwa tempat penampungan air yang paling banyak ditemukan jentik adalah bak mandi, yaitu sebesar 22,4 dari 100 rumah yang terdapat bak mandi di Provinsi Papua. Kemudian terdapat drum dan ember penampungan air pada posisi 
ketiga dan keempat yaitu sebesar berturut-turut 19,4 dan 18,5 dari 100 rumah yang terdapat jentik. Dikarenakan di Provinsi Papua termasuk wilayah yang masih kesulitan air, sehingga penduduk selalu menyediakan tempat penampungan air dalam jumlah yang cukup banyak baik di dalam rumah maupun di luar rumah yang tidak tertutup sehingga sangat memungkinkan nyamuk untuk bertelur di tempat-tempat potensial tersebut. Karakteristik perilaku masyarakat Papua dalam pelaksanaan pemberantasan sarang nyamuk tergambar dalam Tabel 1.

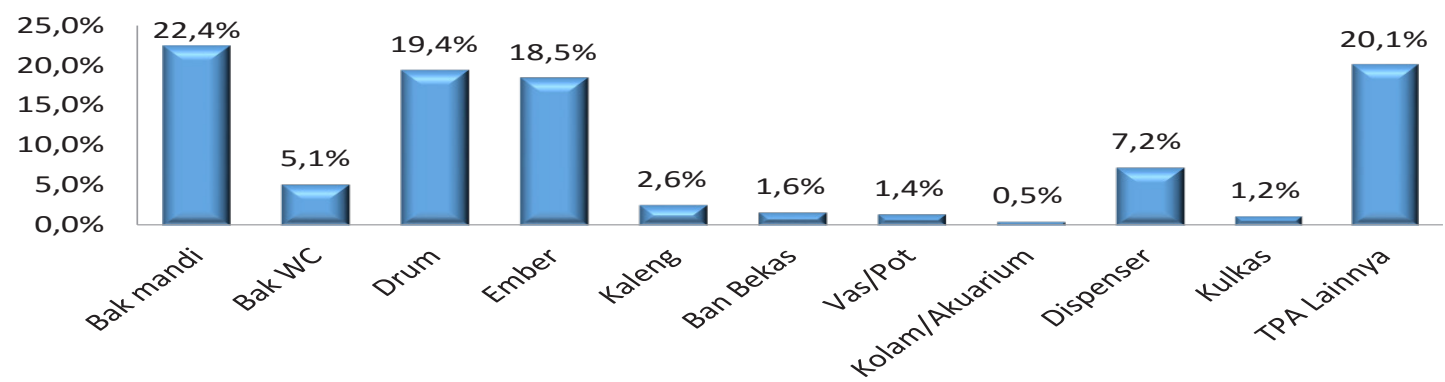

Gambar 1. Kontainer Positif Jentik di Provinsi Papua Tahun 2015

Tabel 1. Karakteristik Perilaku Masyarakat Berdasarkan Peletakan Kontainer, Kontainer Tertutup, Kontainer Dikuras, Memelihara Ikan, dan Penaburan Larvasida.

\begin{tabular}{lccc}
\hline \multicolumn{1}{c}{ Variabel } & & Frekuensi & Persen (\%) \\
\hline Keberadaan Jentik Aedes & tidak ada jentik & 927 & 68,4 \\
& ada jentik & 428 & 31,6 \\
Letak/Tempat & dalam & 980 & 72,3 \\
& luar & 375 & 27,7 \\
Tertutup & tertutup & 321 & 23,7 \\
& tidak tertutup & 1034 & 76,3 \\
Dikuras 1 minggu terakhir & dikuras & 494 & 36,5 \\
& tidak dikuras & 861 & 63,5 \\
Pelihara Ikan & pelihara ikan & 23 & 1,7 \\
& tidak pelihara ikan & 1332 & 98,3 \\
Ditaburi Larvasida & ditaburi & 10 & 0,7 \\
Total & tidak ditaburi & 1345 & 99,3 \\
\hline
\end{tabular}

Tabel 2. Hubungan Perilaku Masyarakat dengan Keberadaan Jentik Aedes sp

\begin{tabular}{|c|c|c|c|c|c|}
\hline \multirow{2}{*}{\multicolumn{2}{|c|}{ Variabel }} & \multicolumn{2}{|c|}{ Keberadaan Jentik Aedes } & \multirow{2}{*}{ Nilai-P } & \multirow{2}{*}{ OR } \\
\hline & & Tidak Ada Jentik & Ada Jentik & & \\
\hline \multirow[t]{4}{*}{ Letak/Tempat } & dalam & 703 & 277 & 0,000 & 1,711 \\
\hline & & $71,73 \%$ & $28,27 \%$ & & \\
\hline & luar & 224 & 151 & & \\
\hline & & $59,73 \%$ & $40,27 \%$ & & \\
\hline \multirow[t]{4}{*}{ Tertutup } & tertutup & 234 & 87 & 0,048 & 1,323 \\
\hline & & $72,90 \%$ & $27,10 \%$ & & \\
\hline & tidak tertutup & 693 & 341 & & \\
\hline & & $67,02 \%$ & $32,98 \%$ & & \\
\hline \multirow[t]{3}{*}{ Dikuras 1 minggu terakhir } & dikuras & 467 & 27 & 0,000 & 15,078 \\
\hline & & $94,53 \%$ & $5,47 \%$ & & \\
\hline & tidak dikuras & 460 & 401 & & \\
\hline \multirow[t]{4}{*}{ Pelihara Ikan } & pelihara ikan & 21 & 2 & 0,031 & 4,937 \\
\hline & & $91,30 \%$ & $8,70 \%$ & & \\
\hline & tidak pelihara ikan & 906 & 426 & & \\
\hline & & $68,02 \%$ & $31,98 \%$ & & \\
\hline \multirow[t]{4}{*}{ Ditaburi Larvasida* } & ditaburi & 8 & 2 & 0,436 & 1,854 \\
\hline & & $80,00 \%$ & $20,00 \%$ & & \\
\hline & tidak ditaburi & 919 & 426 & & \\
\hline & & $68,33 \%$ & $31,67 \%$ & & \\
\hline
\end{tabular}

* tidak signifikan 
Jumlah tempat penampungan air yang diperiksa sebanyak 1355 kontainer. Sebesar $68,4 \%$ kontainer tidak ditemukan jentik dan $31,6 \%$ ditemukan jentik. Sebagian besar kontainer diletakkan di dalam rumah $(72,3 \%)$. Namun sebesar 76,3\% kontainer tersebut dalam kondisi tidak tertutup. Perilaku masyarakat untuk menguras kontainer dalam 1 minggu terakhir masih kurang karena hanya sebesar 36\% dan sebesar $63,5 \%$ tidak dikuras 1 minggu terakhir. Rumah tangga yang memelihara ikan hanya sebesar $1,7 \%$ dan $98,3 \%$ tidak memelihara ikan. Kontainer yang ditaburi larvasida memiliki persentase sangat kecil yaitu $0,7 \%$ dibandingkan dengan yang tidak ditaburi larvasida (Tabel 1).

Tempat penampungan air/kontainer yang diperiksa adalah kontainer milik rumah tangga tersebut dan digunakan untuk kegiatan sehari-hari oleh anggota rumah tangga. Peletakan kontainer yang dilakukan masyarakat pada umumnya merupakan tindakan yang disengaja, masyarakat meletakkan kontainer di dalam ataupun di luar rumah berdasarkan kebutuhan mereka. Berdasarkan Tabel 2, hubungan perilaku masyarakat terhadap keberadaan jentik memiliki pengaruh yang signifikan. Peletakan kontainer, penutupan kontainer, pengurasan kontainer, pemeliharaan ikan berpengaruh nyata terhadap ada dan tidaknya jentik vektor. Hal ini dapat ditunjukkan melalui nilai $p$ yang kurang dari 0,05 . Sedangkan penaburan larvasida tidak berpengaruh nyata terhadap keberadaan jentik di Provinsi Papua.

Tabel 2 memberikan informasi seberapa besar pengaruh peletakan kontainer, apakah kontainer tersebut ditutup atau tidak, apakah kontainer tersebut dikuras dalam 1 minggu terakhir atau tidak, apakah keluarga tersebut memelihara ikan di dalam kontainer dan apakah keluarga tersebut menaburi larvasida dalam setiap kontainer di dalam rumah atau tidak terhadap ada dan tidak nya jentik di dalam suatu rumah. Dapat diamati bahwa menurut hasil analisis nilai $p$ variabel peletakan, penutupan, pengurasan dan pelihara ikan memiliki nilai $p$ kurang dari 0,05 dan variabel penaburan larvasida menunjukkan angka 0,436 dan nilai odds ratio bernilai 1,854.

Faktor eksternal dapat ditunjukkan pada Tabel 2, bahwa ada perbedaan proporsi peletakan kontainer di dalam rumah dengan peletakan kontainer di luar rumah dengan nilai $p$ sebesar 0,000. Dari keseluruhan kontainer yang diletakkan di dalam rumah, $28,27 \%$ positif jentik, sedangkan dari keseluruhan kontainer yang diletakkan di luar rumah, 40,3\% kontainer positif jentik. Dapat dilihat perbandingan jika kontainer diletakkan di dalam rumah dan di luar rumah antara tidak ada jentik dan ada jentik adalah 7:3 dan 6:4. Dari hasil analisis diperoleh nilai $\mathrm{OR}=1,711$, artinya kontainer yang diletakkan di luar rumah memiliki peluang 1,711 kali positif jentik Aedes sp. dibandingkan dengan kontainer yang diletakkan di dalam rumah. Kontainer yang tertutup juga memiliki pengaruh terhadap ada tidak nya jentik. Tabel 2 menjelaskan bahwa kontainer tertutup hanya terdapat sebanyak $27,10 \%$ jentik. Sedangkan kontainer yang tidak tertutup terdapat $32,98 \%$ jentik. Nilai OR menunjukkan nilai 1,323 yang bermakna kontainer yang tidak tertutup memiliki peluang 1,323 kali terdapat jentik dibandingkan dengan kontainer yang tertutup.

\section{PEMBAHASAN}

Keberadaan jentik nyamuk merupakan indikator dari potensi keterjangkitan masyarakat akan DBD. Jentik nyamuk ini dapat berkembang pada wadah-wadah di sekitar pemukiman. Sesuai pernyataan Hasyimi, dkk ${ }^{23}$ bahwa salah satu faktor yang membuat berlimpahnya nyamuk Aedes sp. dikarenakan penggunaan tempat penampungan air yang berlebihan, hal ini disebabkan karena penduduk banyak menyimpan air pada bejana penampungan air untuk keperluan sehari-hari, karena mereka khawatir suatu waktu air yang disalurkan oleh pemerintah tidak tersedia secara kontinyu, sehingga dengan banyaknya tempat-tempat penyimpanan air maka akan terakumulasinya tempat perindukan nyamuk.

Perilaku dari masyarakat akan sangat menentukan tingkat kesehatan dari masyarakat itu sendiri. Perilaku masyarakat yang baik akan memberikan dampak yang baik bagi kesehatan, dan sebaliknya perilaku masyarakat yang tidak baik akan berdampak buruk bagi kesehatannya. Seperti halnya penyakit lain, perilaku masyarakat juga akan menentukan keterjangkitan DBD di tengah masyarakat. Peran serta masyarakat dalam upaya mengatasi masalah DBD bergantung pada adanya motivasi dalam masyarakat. ${ }^{4}$ Perilaku masyarakat ditentukan oleh faktor internal dan faktor eksternal dari masyarakat tersebut. Beberapa faktor internal dari perilaku masyarakat terhadap PSN-DBD seperti pendidikan, status pekerjaan, status ekonomi, pengetahuan, sikap, ketersediaan sarana dan prasarana dan 
keterpaparan penyuluhan telah dipelajari dalam penelitian yang dilakukan oleh Hardayati, dkk. $^{24}$ Pendidikan memberikan pengaruh bermakna pada masyarakat terhadap PSN-DBD $(p=0,039)$. Masyarakat yang berpendidikan rendah mempunyai perilaku baik terhadap PSNDBD (nilainya $71,9 \%$ ) dibandingkan dengan masyarakat yang pendidikannya tinggi (nilainya sebesar 50\%). Penelitian yang dilakukan Ekaputra $^{25}$ memberikan hasil bahwa perilaku penghuni rumah memiliki pengaruh yang sangat besar terhadap keberadaan jentik yakni sebesar 11,6 kali $(95 \% \mathrm{CI}: 2,98-45,13)$ dan variabel kesehatan lingkungan berperan sebesar 4,9 kali (95\%CI:1,56-15,15). Variabel kesehatan yang diteliti pada penelitian yang dilakukan oleh Ekaputra $^{25}$ salah satunya adalah keberadaan kontainer dan tutup kontainer.

Hasil penelitian ini memberikan informasi bahwa peletakan wadah-wadah yang memicu genangan air diletakkan di luar rumah akan berpeluang lebih besar menjadi tempat perindukan nyamuk Aedes sp. daripada yang diletakkan di dalam rumah, kecuali jika wadahwadah tersebut diletakkan terbalik. Penelitian yang dilakukan oleh Suyasa dkk, ${ }^{26}$ membuktikan ada hubungan antara keberadaan kontainer dengan keberadaan vektor DBD. Tempat perindukan nyamuk yang potensial adalah tempat penampungan air seperti bak mandi/ WC, tempayan, drum, kaleng bekas, dan lainlain. ${ }^{27}$ Sejalan dengan penelitian yang telah dilakukan oleh Suyanto dkk, ${ }^{28}$ nyamuk Aedes sp. lebih menyukai tempat-tempat penampungan air di dalam atau di sekitar rumah yang berupa genangan air yang tertampung di suatu tempat atau bejana yang tidak berhubungan langsung dengan tanah seperti drum, tempayan, ember, bak mandi, pelepah pisang, potongan bambu, tempurung kelapa, dan vas bunga. Peletakan tempat penampungan air dan penutupan kontainer berpengaruh nyata terhadap ada tidaknya jentik dalam suatu kontainer. Tempat penampungan air (TPA) potensial sebagai tempat perindukan nyamuk (breeding place), salah satunya adalah genangan air yang terdapat di dalam suatu wadah atau kontainer. Penutupan wadah juga berpengaruh secara signifikan daripada wadah yang tidak diberi tutup akan memicu sebagai tempat perindukan nyamuk. Kontainer tertutup lebih sering mengandung jentik dibandingkan TPA yang terbuka karena penutupnya jarang terpasang dengan baik dan sering dibuka untuk mengambil air. Tempayan dengan penutup yang longgar seperti itu lebih disukai nyamuk untuk bertelur karena ruangan di dalamnya lebih gelap daripada tempat air yang tidak tertutup sama sekali. $^{29}$

Dari keseluruhan tempat penampungan air yang diperiksa, dapat dilihat hasil yang sangat signifikan perbedaan tempat penampungan air yang dikuras minimal seminggu sekali yang tidak berjentik dan ada jentik memiliki perbandingan 95:5. Hasil analisis menunjukkan nilai $\mathrm{OR}=15,078$, artinya tempat penampungan air yang tidak dikuras memiliki peluang 15 kali positifjentik dibandingkan dengan kontainer yang rajin dikuras seminggu sekali. Dalam penelitian yang dilakukan Ridha dkk, ${ }^{30}$ jenis kontainer yang banyak ditemukan jentik adalah bak mandi, drum dan tempayan. Penelitian ini sesuai dengan penelitian yang dilakukan Yotopranoto ${ }^{18}$ di beberapa kota di Indonesia menunjukkan tempat perindukan yang paling potensial adalah di kontainer yang digunakan untuk keperluan sehari-hari seperti drum, tempayan, bak mandi, bak WC, ember, dan sejenisnya. Hal ini sejalan dengan program pemerintah $3 \mathrm{M}$ plus yang salah satunya adalah menguras bak mandi minimal seminggu sekali.

Pemeliharaan predator jentik (ikan) dalam kontainer memiliki nilai signifikan yang cukup tinggi. Rasio tidak terdapat jentik dengan terdapat jentik yaitu 91:9. Hasil ini cukup signifikan membuktikan bahwa memelihara ikan dapat mengurangi populasi jentik dalam kontainer/tempat penampungan air. Nilai OR menunjukkan bahwa kontainer yang tidak terdapat ikan, memiliki risiko sebesar 4,937 kali untuk positif jentik daripada kontainer yang didalamnya terdapat ikan. Penelitian yang dilakukan oleh Sofiana ${ }^{22}$ membuktikan bahwa ikan merupakan pengendali jentik Ae. aegypti yang aman untuk digunakan di masyarakat.

Penaburan larvasida tidak berpengaruh nyata terhadap banyaknya larva/jentik dalam suatu rumah tangga. Hal ini diindikasikan terjadi resistensi jentik terhadap larvasida yang digunakan oleh masyarakat. Pengendalian DBD menggunakan insektisida dapat memicu terjadinya resistensi jika pengawasan dalam pemakaiannya tidak dilakukan dengan baik sehingga program pembersihan lingkungan yang dikenal dengan program PSN, program $3 \mathrm{M}$ plus (Menguras, Menutup, Mengubur, dan Mendaur Ulang) merupakan program yang juga 
harus dilaksanakan terus menerus karena untuk menanggulangi peningkatan kasus DBD yang terus menerus, maka program penanggulangannya harus dilakukan secara terintegrasi dengan baik yaitu dengan tetap menguras tempat air 3 bulan 1 kali jika menggunakan temephos dan 1 kali dalam 1 minggu jika tidak menggunakan Temephos, menutup genangan air dan mengubur barang-barang yang memungkinkan akan menjadi penampungan air yang menjadi tempat perindukan vektor epidemi dan larva vektor epidemi. ${ }^{31}$ Laporan resistensi Larva Ae. aegypti terhadap temephos sudah ditemukan di beberapa negara seperti Brazil, Bolivia, Argentina, Venezuela, Kuba, French Polynesia, Karibia, dan Thailand. ${ }^{32}$ Hasil penelitian serupa terjadi di DKI Jakarta tahun 2006 oleh Shinta dan Sukowati, Banjarmasin Barat, Surabaya, Palembang, dan Bandung juga menunjukkan adanya resistensi tingkat rendah serta Banjarbaru bagian Barat menunjukkan status toleran bahkan cenderung resisten. Di Tanjung Priuk menunjukkan bahwa pemberian larvasida tidak memberikan pengaruh terhadap kematian jentik Aedes sp. ${ }^{33}$

Keterbatasan penelitian ini hanya mencakup variabel perilaku hidup sehat masyarakat yang ada dalam riset khusus vektor dan reservoir saja. Penelitian ini tidak melihat perubahan kepadatan jentik akibat intervensi yang diberikan serta tidak mengukur resistensi nyamuk akibat penggunaan larvasida ataupun insektisida dengan dosis yang kurang tepat. Serta waktu penelitian yang terlalu singkat untuk melihat perubahan di masyarakat. Penelitian ini akan memberikan hasil yang nyata jika dilakukan dalam jangka panjang minimal 1-3 tahun. Hal ini sesuai pernyataan Sukowati ${ }^{34}$ bahwa partisipasi masyarakat merupakan proses panjang dan memerlukan ketekunan, kesabaran dan upaya dalam memberikan pemahaman dan motivasi kepada individu, kelompok, masyarakat, bahkan pejabat secara berkesinambungan.

\section{KESIMPULAN}

Berdasarkan hasil analisis yang telah dilakukan, perilaku masyarakat meletakkan tempat penampungan air/kontainer, menutup/ tidak tempat penampungan air tersebut, pengurasan tempat penampungan air seminggu sekali dan memelihara ikan predator jentik Aedes sp. dalam kolam atau bak air, sangat berpengaruh terhadap ada tidaknya jentik Aedes sp.. Hal ini menunjukkan bahwa peran serta masyarakat sangat dibutuhkan dalam pengendalian penyakit demam berdarah dengue karena perilaku masyarakat sangat berpengaruh nyata terhadap kesehatan lingkungan. Berawal dari lingkup keluarga, monitoring terhadap tempat penampungan air di sekitar rumah sangat berpengaruh nyata dalam program pemberantasan sarang nyamuk sebagai langkah awal pengendalian penyakit DBD. Hal penting berdasarkan penelitian ini yang perlu diperhatikan adalah peletakan tempat penampungan air/ kontainer sebaiknya di dalam rumah dan dalam kondisi tertutup dan dikuras minimal seminggu sekali serta jika terpaksa meletakkan tempat penampungan air di luar rumah, sebaiknya diberi predator jentik (ikan). Mengurangi penggunaan larvasida dapat berdampak positif untuk lingkungan dan mengurangi angka resistensi jentik vektor terhadap paparan larvasida.

\section{SARAN}

Berdasarkan hasil penelitian ini dengan didukung oleh penelitian sebelumnya, pengendalian jentik Aedes sp. dapat dilakukan oleh semua orang mulai dari lingkup terkecil diri sendiri dan keluarga. Peran keluarga perlu lebih ditingkatkan lagi dan didukung oleh peran petugas kesehatan dalam hal monitoring dan evaluasi program pengendalian penyakit DBD. Kesadaran tentang lingkungan sudah seharusnya dimiliki oleh warga masyarakat karena mencegah dan menanggulangi kejadian DBD bukan hanya tugas pemerintah namun juga peran serta masyarakat sangat diperlukan. Program PSN adalah program pemerintah yang dirasa sangat efektif jika diaplikasikan untuk keluarga di Indonesia. Data dan informasi Riset Khusus Vektora dapat dijadikan dasar pemerintah untuk menentukan kebijakan dan penyempurnaan program eliminasi DBD di Indonesia. PSN dinilai sangat efektif dalam mengurangi populasi nyamuk dan angka kesakitan akibat DBD.

\section{UCAPAN TERIMA KASIH}

Ucapan terima kasih kami sampaikan kepada Kepala Badan Penelitian dan Pengembangan Kesehatan yang telah memberikan dukungan penuh kegiatan Riset Khusus Vektor dan Reservoir Penyakit beserta Kepala Balai Besar Penelitian dan Pengembangan Vektor dan Reservoir Penyakit Salatiga dan Ketua Panitia Pembina Ilmiah B2P2VRP (Dra. Widiarti, M.Kes) yang telah membina dalam penulisan 
artikel, memberi masukan dan saran demi terselesaikannya artikel ini. Kami sampaikan terima kasih kepada Ketua Laboratorium (Dr. Dwi Hapsari Tjandrarini) dan teman-teman di Manajemen Data yang telah memberikan semangat dan dorongan untuk selalu konsisten menulis karya tulis ilmiah.

\section{DAFTAR PUSTAKA}

1. Kementerian Kesehatan Republik Indonesia. Pendekatan keluarga dalam pencapaian prioritas pembangunan kesehatan. In: Pedoman umum program Indonesia sehat dengan pendekatan keluarga. Jakarta: Kementerian Kesehatan RI; 2016:19-33.

2. Kementerian Kesehatan Republik Indonesia. Data dan informasi profil kesehatan indonesia tahun 2017. 1st ed. (drg. Rudy Kurniawan, M. Kes Boga Hardhana, S.Si, MM Yudianto, SKM MS, ed.). Jakarta: Pusat Data dan Informasi Kementerian Kesehatan Republik Indonesia; 2017.

3. Chadijah S, Rosmini, Halimudin. Peningkatan peranserta masyarakat dalam pelaksanaan Pemberantasan Sarang Nyamuk DBD (PSN-DBD) di dua kelurahan di Kota Palu Sulawesi Tengah. Media Litbang Kesehat. 2011;21(4):184-190.

4. Prasetyowati H, Santya RNRE, Nurindra RW. Motivasi dan peran serta masyarakat dalam pengendalian populasi Aedes sp. di Kota Sukabumi. J Ekol Kesehatan. 2015;14(2):106-115.

5. 5. Bahtiar Y. Hubungan pengetahuan dan sikap tokoh masyarakat dengan perannya dalam pengendalian demam berdarah di wilayah puskesmas Kawalu Kota Tasikmalaya. Aspirator. 2012;4(2).

6. Sutari. Diagnosis, pengobatan, pencegahan dan pengendalian demam berdarah. Jakarta: EGC; 2004.

7. Lawira AM. Peran keluarga dan petugas kesehatan terhadap penanggulangan penyakit demam berdarah dengue di wilayah Puskesmas Talise. J Ilmu Kesehat POLTEKITA. 2015;1(18):867-876.

8. Pratiknyo H. Teknik monitoring nyamuk. Fakultas Biologi. (Soedirman UJ, ed.). Purwokerto; 2014.

9. Higa Y. Dengue vectors and their spatial distribution. Trop Med Heal. 2011;39(4):17-27.
10. Pratama GY. Nyamuk anopheles sp. dan faktor yang mempengaruhi di Kecamatan Rajabasa, Lampung Selatan. J Major. 2015;4(1):20-27.

11. Departemen Kesehatan RI. Petunjuk teknis pemberantasan nyamuk penular DBD. Jakarta: Departemen KEsehatan; 1998.

12. Soedarto. Demam berdarah dengue: Dengue Haemorrhagic Fever. Jakarta: Sagung Seto; 2012.

13. Garna H. Buku ajar divisi infeksi dan penyakit tropis. Jakarta: Sagung Seto; 2013.

14. Andarmoyo S, Andoko SJ. Hubungan pengetahuan keluarga tentang penyakit DHF dengan sikap keluarga dalam pencegahan penyakit DHF. J Florence. 2013; VI(2).

15. Pramestuti N, Sunaryo. Surveilans Aedes aegypti di daerah endemis demam berdarah dengue. J Kesehat Masy Nasional. 2014;8(8):423-429.

16. Departemen Kesehatan RI. Tata laksana demam berdarah dengue. Jakarta: Departemen Kesehatan RI; 2008.

17. Departemen Kesehatan RI. Modul latihan kader dalam pemberantasan sarang nyamuk demam berdarah dengue. Jakarta: Departemen Kesehatan RI; 1996.

18. Yotopranoto S, Subekti S, Rosmanida S. Dinamika populasi vektor pada lokasi dengan kasus demam berdarah dengue yang tinggi di Kotamadya Surabaya. Maj Kedokt Trop Indones. 2008;9(1-2).

19. Kinansi RR, Widjajanti W. Kepadatan Jentik vektor demam berdarah dengue di daerah endemis di Indonesia (Sumatera Selatan, Jawa Tengah, Sulawesi Tengah Dan Papua). J Ekol Kesehatan. 2017;16(1):1-9.

20. Hasyumi M. Perilaku nyamuk Aedes aegypti berkaitan dengan penggunaan ovitrap di DKI Jakarta. Media Litbang Kesehat 13(4) 54 57. 2003;13(4):54-57.

21. Okumu FO, Knols BGJ, Fillinger U. Larvacidal effect of a Neem (Azadirachta indica) oil formulation on the malaria vector Anophleles gambiae. Malar J. 2007;6:63.

22. Sofiana L. Uji lapangan ikan sebagai predator alami larva Aedes aegypti di masyarakat (studi kasus di daerah endemis DBD Kelurahan Gajahmungkur Kota Semarang). Unnes J Public Heal. 2013;2(4):1-9.

23. Hasyimi H, Soekirno M. Pengamatan tempat perindukan Aedes aegypti pada 
tempat penampungan air rumah tangga pada masyarakat pengguna air olahan. J Ekol Kesehatan. 2004;3(1).

24. HardayatiW, Mulyadi AD. Analisis perilaku masyarakat terhadap angka bebas jentik dan demam berdarah dengue di Kecamatan Pekanbaru Kota, Riau. J Ilmu Lingkung. 2011;5(1):1-9.

25. Ekaputr IB, Ani LS, Suastika K. Analisis faktor-faktor yang berhubungan dengan keberadaan jentik Aedes aegypti di Puskesmas III Denpasar Selatan. Public Health and Preventive Medicine Archive. 2013; 1(2): 189-197.

26. Suyasa ING, Putra N.AryantaIWR. Hubungan faktor lingkungan dan perilaku masyarakat dengan keberadaan vektor demam berdarah dengue (DBD) di wilayah kerja Puskesmas I Denpasar Selatan. Ecothropic. 2012; 3(1):16.

27. Depkes RI. Petunjuk teknis penemuan, pertolongan, dan pelaporan penderita penyakit DBD. Dirjen PPM dan PLP. in Kajian Masalah Kesehatan: Demam Berdarah Dengue. Jakarta: Badan Penelitian Dan Pengembangan Kesehatan; 2004.

28. Suyanto S, Darnoto S, Astuti D. Hubungan pengetahuan dan sikap dengan praktek pengendalian nyamuk Aedes aegypti di Kelurahan Sangkrah Kecamatan Pasar Kliwon Kota Surakarta. J Kesehatan. 2011;4(1):1-132.

29. Sungkar S. Demam berdarah dengue 1st Edition. 1st ed. Jakarta: Yayasan Penerbitan Ikatan Dokter Indonesia; 2002.

30. Ridha MR, Rahayu N, Rosvita NA, Setyaningtyas DA. The relation of environmental condition and container to the existance of the Aedes aegypti larvae in dengue haemorrhagic fever endemic areas in Banjarbaru. J Buski. 2013;4(3):133-137.

31. Ridha MR, Nisa K. Larva aedes aegypti sudah toleran terhadap temepos di kota Banjarbaru, Kalimantan Selatan. J vektora . 2012;III(2):93-111.

32. Gafur A, Mahrina H. Kerentanan larva Aedes aegypti dari Banjarmasin Utara terhadap Temephos. Tesis. Bioscientiae III (2). 2006.

33. Hasyimi M, Suwarto WI, Mardiana, Suyitno $\mathrm{S}$, et al. Pengaruh temephos terhadap perolehan telur nyamuk Aedes aegypti L di Cipinang Muara Jakarta. 2006. J Entomol Indones. 2006;3:14-19.

34. Sukowati S. Masalah vektor demam berdarah dengue dan upaya pengendaliannya. Bul Jendela Epidemiol. 2010;2(2). 